\title{
Corals shed bacteria as a potential mechanism of resilience to organic matter enrichment
}

\author{
Melissa Garren and Farooq Azam \\ Scripps Institution of Oceanography, Marine Biology Research Division, La Jolla, CA, USA
}

\begin{abstract}
Understanding the mechanisms of resilience of coral reefs to anthropogenic stressors is a critical step toward mitigating their current global decline. Coral-bacteria associations are fundamental to reef health and disease, but direct observations of these interactions remain largely unexplored. Here, we use novel technology, high-speed laser scanning confocal microscopy on live coral (Pocillopora damicornis), to test the hypothesis that corals exert control over the abundance of their associated bacterial communities by releasing ('shedding') bacteria from their surface, and that this mechanism can counteract bacterial growth stimulated by organic inputs. We also test the hypothesis that the coral pathogen Vibrio coralliilyticus can evade such a defense mechanism. This first report of direct observation with high-speed confocal microscopy of living coral and its associated bacterial community revealed a layer $(3.3-146.8 \mu \mathrm{m}$ thick) on the coral surface where bacteria were concentrated. The results of two independent experiments showed that the bacterial abundance in this layer was not sensitive to enrichment (5 $\mathrm{mg} \mathrm{l}^{-1}$ peptone), and that coral fragments exposed to enrichment released significantly more bacteria from their surfaces than control corals $\left(P<0.01 ; 35.9 \pm 1.4 \times 10^{5}\right.$ cells cm $\mathrm{cm}^{-2}$ coral versus $1.3 \pm 0.5 \times 10^{5} \mathrm{cells} \mathrm{cm}^{-2}$ coral $)$. Our results provide direct support to the hypothesis that shedding bacteria may be an important mechanism by which coral-associated bacterial abundances are regulated under organic matter stress. Additionally, the novel ability to watch this ecological behavior in real-time at the microscale opens an unexplored avenue for mechanistic studies of coral-microbe interactions.
\end{abstract}

The ISME Journal (2012) 6, 1159-1165; doi:10.1038/ismej.2011.180; published online 22 December 2011 Subject Category: microbe-microbe and microbe-host interactions

Keywords: coral holobiont; resilience; microscale; organic matter; Vibrio coralliilyticus; coral-bacteria association

\section{Introduction}

Coral reef resilience to the suite of anthropogenic stressors they currently face has been an active area of research in recent years. There have been substantial discussions in the literature about how to define resilience (Nystrom et al., 2008), how to manage reefs in ways that encourage it (Hughes et al., 2010), and how to synthesize case studies to elucidate the large-scale mechanisms that determine whether a stony-coral-dominated ecosystem can resist a phase-shift or rebound from one (McClanahan et al., 2002; Norstrom et al., 2009). However, very little attention has been given to the small-scale mechanisms relevant to the microbial processes that determine the resilience of individual corals to a given stressor. Delineating the mechanisms by which individual colonies resist or recover from environmental stress may be a critical link

Correspondence: M Garren, Scripps Institution of Oceanography, Marine Biology Research Division, 8750 Biological Grade, Hubbs Hall, Room 4200, La Jolla, CA 92037, USA.

E-mail: melissa.garren@gmail.com

Received 29 July 2011; revised 23 October 2011; accepted 3 November 2011; published online 22 December 2011 for understanding and predicting larger reef- and region-wide patterns of resilience.

Recently, researchers have begun to examine the potential for climate-driven impacts on coralmicrobe associations and the corresponding influence on the function of coral-dominated reef ecosystems (Mouchka et al., 2010; Meron et al., 2011). While climate-driven impacts are of great concern to the longevity of all reefs, excessive organic matter input is another acute global threat degrading reefs worldwide (Fabricius, 2005). Coral-microbe relationships can be sensitive to organic matter inputs (Kline et al., 2006; Smith et al., 2006; Voss and Richardson, 2006; Thurber et al., 2009), and resilience at the single colony level has been observed on short time scales (Garren et al., 2009). Elucidating the underlying mechanisms of resilience to organic pollution may clarify how and why large-scale phase shifts occur on enriched reefs (that is, what triggers the 'tipping point') and could directly inform management actions.

A curious finding has been that corals exposed to chronic enrichment from a wastewater treatment plant did not harbor more bacteria on their surface than corals at reference reefs (Garren and 
Azam, 2010), and the same has been observed for corals exposed to large amounts of fish-pen effluent harboring an order-of-magnitude more bacteria than the typical reef water for the area (Garren et al., 2009). There were differences in the community composition between the samples from the reference and treatment sites but no significant difference in the corals' surface bacterial abundance. We do know that a tipping point can exist in certain disease states where corals become more heavily colonized than in their healthy state (Luna et al., 2007), but the underlying mechanisms are not known.

Shedding of bacteria from mucosal surfaces is a common occurrence in many animals, for instance the human gut (Neish, 2009); however, the ability to observe and quantify this behavior in reef-building corals had not been possible until recently. The observation of live coral-microbe interactions had not been successful previously for a combination of reasons that include a strong autofluorescence signal from the coral that can overwhelm signal from stains and the performance abilities of the last generation microscopes, which did not offer the speed, detection sensitivity, resolution, and working distance needed to simultaneously image the millimeter scale coral animal and the micrometer scale bacterial associates in real time. The newest generation of confocal microscopes alleviates these barriers with drastically improved sensitivity, resolution and speed (imaging up to 150 frames s$^{-1}$ on living coral).

The goal of this study was to employ novel technology to test the hypotheses that the coral Pocillopora damicornis is able to exert some control over the abundance of its associated bacterial communities by releasing ('shedding') bacteria from their surface, and that a known pathogen, Vibrio coralliilyticus, may have the ability to overcome such a mechanism. We tested these hypotheses in situ on live coral using a high-speed laser scanning confocal microscope to directly observe and quantify the natural shedding rate and the subsequent response to organic enrichment. To the best of our knowledge, this is the first time that the natural assemblage of coral-associated bacteria have been observed in situ on live coral, and their ecological interactions documented in real time.

\section{Materials and methods}

Coral and bacterial cultures

The reef-building coral $P$. damicornis was used for this study. Colonies were cultured at $28^{\circ} \mathrm{C}$ on a $12 \mathrm{~h}$ light $/ 12 \mathrm{~h}$ dark cycle in flow-through seawater aquaria at Scripps Institution of Oceanography (La Jolla, CA, USA). Small fragments $(5-10 \mathrm{~mm}$ in length) were clipped from three individual donor colonies and allowed to acclimate for $48 \mathrm{~h}$. For all experiments, fragments were transferred to individual $50 \mathrm{ml}$ closed-system chambers containing $0.2 \mu \mathrm{m}$ filtered, autoclaved seawater (FASW) with a $0.2-\mu \mathrm{m}$ filtered air supply. The temperature was maintained by placing the chambers in a $28^{\circ} \mathrm{C}$ water bath, and light cycling remained the same.

The coral pathogen V. coralliilyticus, known to infect P. damicornis (Ben-Haim et al., 2003), was cultured at $28^{\circ} \mathrm{C}$ in FASW amended with $0.374 \mathrm{gl}^{-1} 2216$ Marine Broth (Difco, Franklin Lakes, NJ, USA). Cells were grown for $24 \mathrm{~h}$ to a concentration of $\sim 10^{8}$ cells ml ${ }^{-1}$ before staining with $1 \mu \mathrm{g} \mathrm{ml}^{-1} 4^{\prime}$,6-diamidino-2-phenylindole (DAPI), quantifying the cell density (on a $0.2-\mu \mathrm{m}$ black polycarbonate filter (Millipore, Billerica, MA, USA) (following Porter and Feig, (1980))), diluting the stained liquid culture to experimental concentrations using unamended FASW and checking for motility in a chamber well slide (Nunc, Roskilde, Denmark) on an Olympus IX 51 epifluorescence microscope. The aliquots of culture taken for motility assessment were dual-stained with the lipophilic dye FM-4-64fx ( $5 \mu \mathrm{g} \mathrm{ml}^{-1}$; Invitrogen, Carlsbad, CA, USA) to visualize the sheathed flagellum of $V$. coralliilyticus, and they were also observed by dark field microscopy (Supplementary Video 1). The percent motility of the culture was qualitatively observed in comparison with the undiluted culture.

\section{Experimental design}

Three independent experiments were conducted. The first quantified the in situ effects of short-term $(24 \mathrm{~h})$ organic enrichment ( $5 \mathrm{mg} \mathrm{l}^{-1}$ peptone) on the abundance of bacteria naturally associated with the corals. The second quantified the natural rate of particle and bacteria release during a time course through two diel cycles before exposing the corals to enrichment and sampling the time course for an additional $24 \mathrm{~h}$. The third experiment quantified the in situ abundance of pathogen cells adhering to the living coral surface after a short $(1 \mathrm{~h})$ exposure to three different concentrations of pathogen. All data are reported with their associated standard error.

\section{Influence of organic enrichment on shedding in situ} The natural bacterial population was directly quantified on and around the living coral surface using a high-speed laser scanning confocal microscope (Nikon A1-R) with a temperature-controlled chamber maintained at $28^{\circ} \mathrm{C}$ (Supplementary Videos 2-4). Three coral fragments from separate donor colonies were imaged at $T_{0}$, whereas one fragment from each donor colony was exposed to $5 \mathrm{mg} \mathrm{l}^{-1}$ peptone $(\sim 200 \mu \mathrm{M}$ dissolved organic carbon; approximately double the concentration of ambient dissolved organic carbon (ranging from 57 to $93 \mu \mathrm{M}$ on relatively undisturbed reefs (Garren et al., 2009; Tanaka et al., 2011)) to simulate levels observed on heavily polluted reefs (Garren et al., 2009)) in FASW for $24 \mathrm{~h}$, and parallel fragments from the same donor colonies were maintained in FASW without peptone for $24 \mathrm{~h}$ as controls. For sampling, an aliquot of water from each experimental chamber was fixed at 
$T_{24}$ with a final concentration of $2 \% 0.2 \mu \mathrm{m}$-filtered formaldehyde to enumerate bacterial concentrations following Porter and Feig (1980). Coral fragments were removed from the experimental chambers, briefly rinsed in fresh $28^{\circ} \mathrm{C}$ FASW and then stained with $1 \mu \mathrm{g} \mathrm{ml}^{-1}$ DAPI in FASW for $15 \mathrm{~min}$ in cover glass bottom chamber slides (Nunc, USA). A total of 10 different locations on each fragment were imaged in three dimensions (approximately $215 \mu \mathrm{m} \times 215 \mu \mathrm{m} \times 150 \mu \mathrm{m})$ using a $\times 60$ waterimmersion objective (Supplementary Video 3). Individual planes of focus were also imaged at video rate (up to 150 frames s$^{-1}$ ) to record the release of bacteria through time (Supplementary Video 2). Nikon Elements software program was used for both the acquisition and analysis of images. All surface areas and volumes were calculated by thresholding on the DAPI signal and using the area and volume calculation functions of the Elements software (Supplementary Video 4). A Student's $t$-test was used to evaluate the significance of the difference between the mean abundances and frequency of dividing cells of bacteria found on and shed from corals with and without exposure to peptone for both experiments.

\section{Natural rate of particle and bacteria release through two diel cycles}

To quantify the rates of bacteria and particle release from corals over time, a larger volume than the chamber slides could accommodate was needed, and thus counting was done ex situ (that is, by counting fixed samples placed on filters). Four fragments from the same donor colony were kept in $25 \mathrm{ml}$ of FASW in $50 \mathrm{ml}$ experimental chambers for $72 \mathrm{~h}$. Ninety percent of the water $(22.5 \mathrm{ml})$ was replaced with fresh FASW at 1, 3, $6 \mathrm{~h}$, and then every $6 \mathrm{~h}$ following, for a total of $48 \mathrm{~h}$. At $T_{48}$, the FASW was amended with $5 \mathrm{mgl}^{-1}$ peptone to expose the corals to organic enrichment. Ninety percent of the water was again removed and replaced with fresh FASW plus peptone after $1 \mathrm{~h}$ $\left(T_{49}\right), 3 \mathrm{~h}\left(T_{51}\right), 6 \mathrm{~h}\left(T_{54}\right)$ and then every $6 \mathrm{~h}$ after that for a total of $24 \mathrm{~h}\left(T_{72}\right)$. The controls consisted of two experimental chambers that never had a coral introduced (the 'blanks') to control for possible environmental contamination during the course of the experiment, and a set of parallel controls for each coral where $2.5 \mathrm{ml}$ of the removed water at each time point was inoculated into a sterile experimental chamber with $22.5 \mathrm{ml}$ of FASW (or FASW + peptone for $T_{48}$ through $T_{72}$ ) to detect in situ growth of bacteria in the water column.

\section{Sampling procedure}

Ten milliliters of removed water from each chamber were fixed with a $2 \%$ final concentration of $0.2 \mu \mathrm{m}$ filtered formaldehyde at each time point. A portion was filtered onto $0.2 \mu \mathrm{m}$ white polycarbonate filters
(Millipore), stained with $1 \times$ Alcian Blue for mucusderived transparent exopolymers (TEP; Alldredge et al., 1993), and $2 \mu \mathrm{g} \mathrm{ml}^{-1}$ DAPI for bacteria and counted on an Olympus IX-51 epifluorescence microscope. TEP abundance was quantified at $\times 100$ magnification, whereas total bacterial abundances and the number of bacteria attached to TEP particles were quantified at $\times 1000$. The number of bacteria counted in each of the controls was subtracted from the number in the corresponding treatment chamber to account for in situ growth of bacteria in the water column during each time period. The dilution culture approach was necessary to keep growth in the water column low enough to detect the bacteria being released from the corals.

Mucus samples were collected from each fragment after a rinse in FASW at $T_{0}$ and $T_{72}$ by air exposure for $3 \mathrm{~min}$ over a sterile $1.5 \mathrm{ml}$ tube. The mucus was fixed with $2 \%$ final concentration $0.2 \mu \mathrm{m}$-filtered formaldehyde and bacteria were counted following a previously published protocol (Garren and Azam, 2010).

A portion of unfixed water from each of the 10 chambers was sampled at $T_{0}$ and $T_{72}$ for total organic carbon. Briefly, water samples were acidified and analyzed on a Shimadzu TOC-V high temperature combustion instrument fitted with an autosampler (Aluwihare Laboratory, Scripps Institution of Oceanography, La Jolla, CA, USA). The total organic carbon concentration of each sample was calculated from an average of four $100 \mu \mathrm{l}$ injections using a five-point potassium hydrogen phthalate standard curve and consensus reference materials (courtesy of Dr Wenhao Chen, Rosenstiel School of Marine and Atmospheric Science).

\section{Pathogen challenge}

A fragment from each of two separate donor colonies was exposed in individual wells of four-chamber well slides maintained at $28{ }^{\circ} \mathrm{C}$ to $1 \mathrm{ml}$ of prestained $V$. coralliilyticus (described above) for $1 \mathrm{~h}$ at one of three concentrations: $5 \times 10^{5}$, $5 \times 10^{6}$, or $5 \times 10^{7}$ cells ml $\mathrm{m}^{-1}$. After $1 \mathrm{~h}$, fragments were briefly rinsed in $28{ }^{\circ} \mathrm{C} \mathrm{FASW}$, placed in a new chamber slide containing $2.5 \mathrm{ml}$ of FASW, and the prestained pathogen cells were directly counted on the live coral surface using confocal microscopy (as described above).

\section{Results and discussion}

Influence of organic enrichment on shedding in situ Direct observation with high-speed confocal microscopy of living coral and its active associated bacterial community revealed a layer on the coral surface above and through the ectoderm where bacteria were concentrated (Figure 1). The thickness of this layer ranged from 3.3 to $146.8 \mu \mathrm{m}$. It was thinnest on the tentacles and thickest on the coenosarc between polyps (Figure 1b). Exposure to 

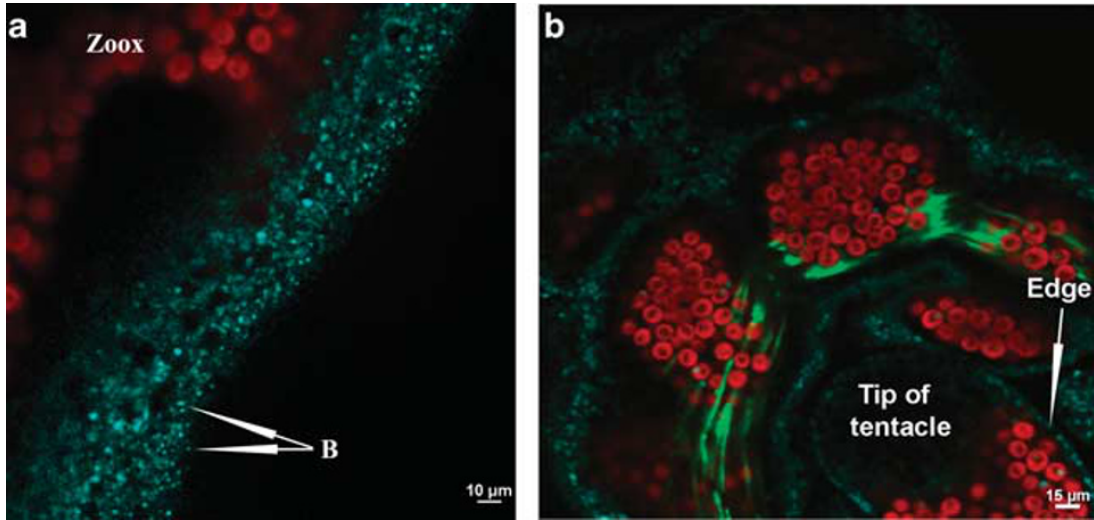

Figure 1 Laser-scanning confocal images of DAPI-stained P. damicornis. (a) An optical slice through the coenosarc of a fragment from the control treatment showing the inner layer of symbiotic dinoflagellates (zooxanthellae (Zoox)) with an outer crust of abundant DAPIstained bacterial cells on the coral surface. Arrows point to individual bacterial cells (B) and the zooxanthellae appear in red due to the autofluorescence of their chlorophyll pigments. (b) A view into a polyp. The tentacle is covering the oral cavity. This image depicts the varying thickness of the bacteria-laden layer. The arrow points to the edge of the tentacle where this layer was thinnest on all corals imaged. The green in natural autofluorescence from the coral animal.
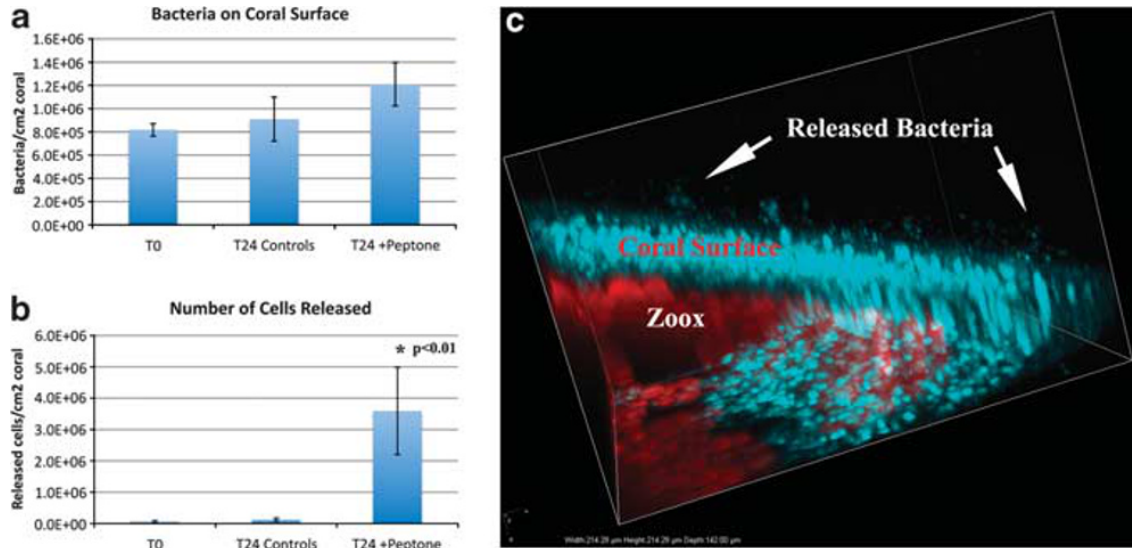

Figure 2 (a) The number of bacteria counted directly on the coral surface at $T_{0}$ and $T_{24}$ with and without peptone enrichment. No significant difference was observed. (b) The average number of bacteria releasing from the surface of the corals at each time point. (c) A representative three-dimensional rendering of a z-stack from a coral in the peptone treatment after $24 \mathrm{~h}$ of exposure showing bacteria, some of which are attached to mucus-like particles, being released into the water just above the coral surface.

organic enrichment did not influence the number of bacteria colonizing the coral surface despite $\sim$ sevenfold higher numbers of bacteria in the surrounding water in the peptone-enriched experimental chambers at $T_{24}$ compared with the control chambers $\left(P<0.01\right.$, an average of $35.2 \pm 1.6 \times 10^{5}$ versus $5.2 \pm 0.4 \times 10^{5}$ cells ml $^{-1}$ in the control chambers). There were no significant differences in coral-associated bacterial abundance among any of the fragments from the $T_{0}\left(6.8-9.7 \times 10^{5}\right.$ cells $\mathrm{cm}^{-2}$ coral; $2.6-5.1 \times 10^{8}$ cells cm $^{-3}$ coral surface layer) and $T_{24}$ controls $\left(4.8-15.6 \times 10^{5} \mathrm{cells} \mathrm{cm}^{-2}\right.$ coral; $1.5-2.2 \times 10^{8}$ cells cm $^{-3}$ coral surface layer) or the $T_{24}$ peptone treatment $\left(7.8-19.0 \times 10^{5}\right.$ cells $\mathrm{cm}^{-2}$ coral; $1.1-4.3 \times 10^{8}$ cells cm $^{-3}$ coral surface layer) (Figure 2a). However, the fragments exposed to peptone released significantly more bacteria from their surfaces than the control fragments in any given moment $(P<0.01$; an average of $35.9 \pm 1.4 \times$ $10^{5}$ cells cm ${ }^{-2}$ coral versus $1.3 \pm 0.5 \times 10^{5}$ cells cm $^{-2}$ coral; Figures $2 \mathrm{~b}$ and $\mathrm{c}$ ). These findings underscore the potential importance of shedding bacteria as a mechanism for regulating the abundance of cells on the coral surface in the face of organic enrichment and substantial increases in bacterial abundance in the surrounding water.

Another notable observation was that the frequency of dividing cells in each coral-associated bacterial community was extremely high, ranging from $25\left(T_{24}\right.$ controls) to $30 \%\left(T_{24}\right.$ peptone treatment) of the total observed population, and not significantly different among treatments. Previous studies of coral mucus found the frequency of dividing cells to range from 3 to $7 \%$ (Garren and Azam, 2010). This observation suggests that the coral-associated bacterial communities may grow rapidly under these experimental conditions. However, we cannot rule out (indeed we consider it likely) that the frequency of dividing cells values in this study were overestimated: some non-dividing 
bacteria may go uncounted in our procedure developed to obtain reliable minimum estimates of bacterial abundance in the dense mucus layer matrix, and therefore these data may underestimate the total abundance and/or preferentially count dividing cells because of their distinctly identifiable cell morphology. In either case, these measurements give minimum estimates of the actual bacterial abundances.

\section{Natural rate of particle and bacteria release through} two diel cycles

Over the course of $72 \mathrm{~h}$, the abundance of bacteria in the surrounding water increased by more than four orders of magnitude (from $1.2 \pm 0.6 \times 10^{2}$ cells ml $^{-1}$ at $T_{0}$ to an average of $9.1 \pm 0.6 \times 10^{6} \mathrm{cells} \mathrm{ml}^{-1}$ at $T_{72}$ ), however, the number of bacteria in the coral mucus did not change significantly (an average of $2.2 \pm 0.4 \times 10^{5} \mathrm{cells} \mathrm{ml}^{-1}$ mucus at $T_{0}$ versus $2.3 \pm 0.6 \times 10^{5}$ cells ml ${ }^{-1}$ mucus at $T_{72}$ (Figures 3a and b)). The rate at which bacteria were released increased during the course of the experiment (from an average of $2.8 \pm 0.5 \times 10^{4} \mathrm{cells} \mathrm{cm}^{-2}$ of coral per $\mathrm{h}$ during day 1 , to $86.7 \pm 12.4 \times 10^{4} \mathrm{cells} \mathrm{cm}^{-2}$ of coral per h during day 2 , to $541.7 \pm 90.0 \times 10^{4} \mathrm{cells} \mathrm{cm}^{-2}$ of coral per $\mathrm{h}$ during day 3 with the peptone enrichment; $P<0.01$; Figure 3c) as did the number of bacteria associated with TEP particles $(P<0.05$; Figures $3 \mathrm{~d}$ and 4 ). The rate of TEP release was not significantly different over the course of the first 2 days; however, after the addition of peptone, it did increase significantly $(P<0.05)$ (from an average of $2.0 \pm 0.5 \times 10^{3}$ TEP particles per $\mathrm{cm}$ of coral per $\mathrm{h}$ during day 2 to $6.7 \pm 0.6 \times 10^{3}$ TEP particles $\mathrm{cm}^{-2}$ of coral per $\mathrm{h}$ during the day with peptone). These numbers implicate the shedding of bacteria as an important component of the mechanism by which corals maintain a stable concentration of bacteria on their surface.

As some components of coral mucus stain as TEP (Goldberg, 2002), the release of heavily colonized TEP particles suggests that these coral fragments can shed substantial numbers of bacteria as they shed their mucus. Not all mucus components stain with Alcian Blue, so there are likely to be many more bacteria attached to mucus particles not observed with this method. Additionally, the coral polyps were filter feeding throughout the experiment and likely removing bacteria and particles from the water column. Given that the corals were the only source of TEP particles in these experimental chambers filled with $0.2 \mu \mathrm{m}$-filtered sterile seawater, these data provide a minimum estimate of the number of bacteria released on mucus particles.

It is also possible that some members of the bacterial community alter their physiology to take advantage of the enriched water environment. Some of the observed bacteria released from the coral surface could have been initiated by the bacteria themselves. However, given the number of bacteria that were released attached to TEP particles, our observations are consistent with the hypothesis that the release of mucus is a part of the mechanism(s) by
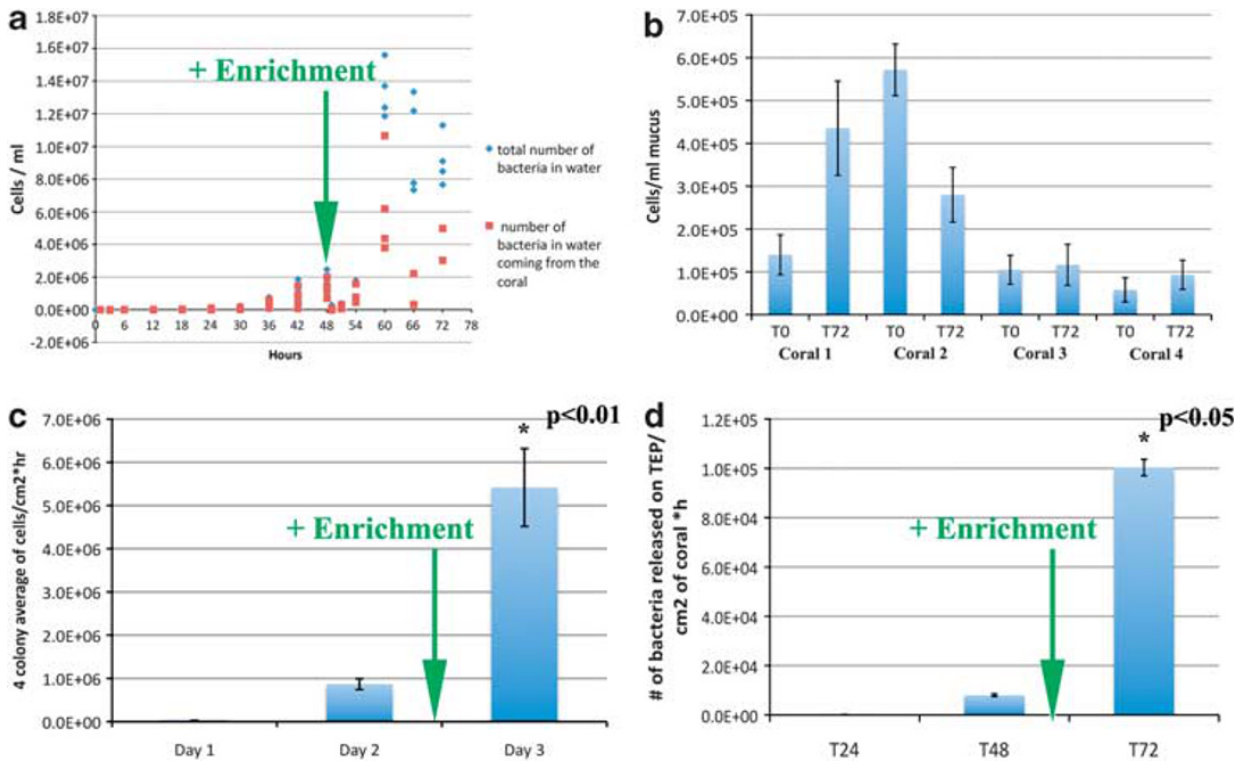

Figure 3 These data are from the diel cycle experiment where bacterial abundances were enumerated ex situ. (a) The total number of bacteria present (from DAPI counts on filters) in the water of the experimental chambers at each time point for each of the four replicates (blue diamonds) as well as the number of bacteria coming from the coral surface at each time point (red squares). The coral contributed the majority of the bacterial cells to the water until the enrichment addition at $T_{48}$ when in situ growth of bacteria in the water increased. (b) The abundance of bacteria in the mucus of each coral colony at $T_{0}$ and $T_{72}$. (c) The average rate of bacterial cell release per cm ${ }^{2}$ of coral per $\mathrm{h}$ for each day. The rate of release increased by $\sim$ fivefold after the addition of peptone. (d) The average rate of bacteria released on TEP particles per day. The rate at which bacteria attached to TEP particles were released increased by $\sim$ twelvefold after the addition of peptone. 



Figure 4 A comparison between TEP particles sampled at $T_{48}$ versus $T_{72}$ during the diel cycle experiment. (a) An overlay at $\times 1000$ magnification of a bright field image showing Alcian-stained TEP particles (T) in dark blue and the same field of view imaged with epifluorescence showing DAPI-stained bacteria (B) in bright blue. These two TEP particles from $T_{48}$ were not heavily colonized. (b) An overlay of bright field and DAPI images acquired in the same way as part (a) depicting heavily colonized TEP particles (T) from $T_{72}$

which coral-associated bacterial population abundance may be controlled. The amount of TEP released increased in response to organic enrichment, suggesting that the coral animal may have a role in regulating bacterial abundance through this mechanism.

\section{Pathogen challenge}

After $1 \mathrm{~h}$ of exposure to $5 \times 10^{5} \mathrm{~V}$. coralliilyticus cells $\mathrm{ml}^{-1}$, the coral fragments had 1.4-3.5 $\times 10^{6}$ pathogen cells $\mathrm{cm}^{-3}$ of coral surface layer. The fragments exposed to $5 \times 10^{6} \mathrm{cells} \mathrm{m}^{-1}$ had 0.9-1.5 $\times 10^{6}$ pathogen cells $\mathrm{cm}^{-3}$ of coral surface layer and the fragments exposed to $5 \times 10^{7}$ cells ml $\mathrm{ml}^{-1}$ had 10.8-29.6 $\times 10^{6}$ pathogen cells $\mathrm{cm}^{-3}$ of coral surface layer. The order of magnitude increase in the number of $V$. coralliilyticus associated with the surface of the $P$. damicornis fragments with the highest exposure suggests that this pathogen may have the ability to overcome the coral's shedding mechanism. The bacterial abundance in the water surrounding the coral fragments during the diel cycle time course reached levels above $10^{7} \mathrm{ml}^{-1}$ starting at $T_{60}$, and yet the abundance of bacteria in the coral mucus at $T_{72}$ did not differ from $T_{0}$, when the bacteria in the water were $\sim 10^{2} \mathrm{ml}^{-1}$. The fairly consistent abundance of the pathogen on the coral surface between the $10^{5}$ and $10^{6}$ cells $\mathrm{ml}^{-1}$ treatments also suggests that there is behavioral regulation of $V$. coralliilyticus' association, likely by both the bacterium and the coral. The pathogen quantifiably associates with the corals at both lower dose levels, but it is only at the highest dose that the number of coral-associated cells increases substantially. The coral may be able to minimize the pathogen's association up to a certain threshold, beyond which the pathogenic bacterium can overcome the control mechanisms. This relationship and mechanism underlying it merit further study. In preliminary experiments, we observed that fluorescent beads (used as a passive control for a bacterial cell) did not accumulate on the coral surface; however, the responses of a larger suite of bacterial strains will be an important component of future work.

\section{Conclusions}

These experimental results highlight the ability of corals to regulate the abundance of bacteria on their surface in the face of organic enrichment stress and drastic increases in water-associated bacterial abundances. Our results suggest that shedding bacteria into the water column is an important component of the mechanism by which corals regulate their associated bacterial abundance, and that they have the ability to use that pathway to cope with organic matter perturbations. By increasing the amount of bacteria and mucus (as TEP) released following exposure to organic enrichment, the corals were able to maintain a relatively stable number of bacteria in their surface-associated community. It is possible that this mechanism may also assist corals in warding off pathogens, though our results using $V$. coralliilyticus suggest that at least one pathogen may be able to evade or overcome such a regulation mechanism. This raises further questions regarding what constitutes an infectious dose in the natural environment, and whether particulate-laden organic matter inputs (such as sedimentation or sewage effluent) might increase the opportunity for pathogens to reach such a dose in microscale hotspots of enrichment. In addition to identifying one potential mechanism of resilience, the novel ability to watch this ecological behavior in real time at the scale at which it actually occurs opens an unexplored avenue for studying coral-microbe interactions. Such a capability makes it possible to distinguish the in situ behaviors of symbiotic versus pathogenic bacteria toward corals, and begin creating an integrated mechanistic understanding of coral health and pathogenesis. 


\section{Acknowledgements}

This work was supported in part by grants from the Gordon and Betty Moore Foundation to FA and from the National Science Foundation (NSF; \#OCE09-62721) to FA. MG was supported by an the NSF Graduate Research Fellowship and the Robert and Patricia Switzer Foundation. We thank F Nosratpour and the Birch Aquarium at Scripps for the $P$. damicornis fragments. We thank L Aluwihare, D Bartlett, K Roy, J Smith, F Malfatti, T Samo and B Pedler for extremely helpful discussions. We are deeply grateful to M Porrachia and L Aluwihare for the TOC measurements and to the members of the Nikon team, especially $\mathrm{M}$ Thieleking, E Cho, K Ng, K Parker and J Parsons. We thank three anonymous reviewers for their help improving this manuscript.

\section{References}

Alldredge AL, Passow U, Logan BE. (1993). The abundance and significance of a class of large, transparent organic particles in the ocean. Deep-Sea Res Part I Oceanogr Res Papers 40: 1131-1140.

Ben-Haim Y, Zicherman-Keren M, Rosenberg E. (2003). Temperature-regulated bleaching and lysis of the coral Pocillopora damicornis by the novel pathogen Vibrio coralliilyticus. Appl Environ Microbiol 69: 4236-4242.

Bourne D, Iida Y, Uthicke S, Smith-Keune C. (2008). Changes in coral-associated microbial communities during a bleaching event. ISME J 2: 350-363.

Fabricius KE. (2005). Effects of terrestrial runoff on the ecology of corals and coral reefs: review and synthesis. Mar Pollut Bull 50: 125-146.

Garren M, Azam F. (2010). New method for counting bacteria associated with coral mucus. Appl Environ Microbiol 76: 6128-6133.

Garren M, Raymundo L, Guest J, Harvell CD, Azam F. (2009). Resilience of coral-associated bacterial communities exposed to fish farm effluent. Plos One 4: e7319.

Goldberg WM. (2002). Feeding behavior, epidermal structure and mucus cytochemistry of the Scleractinian Mycetophyllia reesi, a coral without tentacles. Tissue Cell 34: 232-245.
Hughes TP, Graham NAJ, Jackson JBC, Mumby PJ, Steneck RS. (2010). Rising to the challenge of sustaining coral reef resilience. Trends Ecol Evol 25: 633-642.

Kline DI, Kuntz NM, Breitbart M, Knowlton N, Rohwer F. (2006). Role of elevated organic carbon levels and microbial activity in coral mortality. Mar Ecol Prog Ser 314: 119-125.

Luna GM, Biavasco F, Danovaro R. (2007). Bacteria associated with the rapid tissue necrosis of stony corals. Environ Microbiol 9: 1851-1857.

McClanahan T, Polunin N, Done T. (2002). Ecological states and the resilience of coral reefs. Conserv Ecol 6: 27.

Meron D, Atias E, Kruh LI, Elifantz H, Minz D, Fine M et al. (2011). The impact of reduced $\mathrm{pH}$ on the microbial community of the coral Acropora eurystoma. ISME J 5: 51-60.

Mouchka ME, Hewson I, Harvell CD. (2010). Coralassociated bacterial assemblages: current knowledge and the potential for climate-driven impacts. Integr Comp Biol 50: 662-674.

Neish AS. (2009). Microbes in gastrointestinal health and disease. Gastroenterology 136: 65-80.

Norstrom AV, Nystrom M, Lokrantz J, Folke C. (2009). Alternative states on coral reefs: beyond coralmacroalgal phase shifts. Mar Ecol Prog Ser 376: 295-306.

Nystrom M, Graham NAJ, Lokrantz J, Norstrom AV. (2008). Capturing the cornerstones of coral reef resilience: linking theory to practice. Coral Reefs 27: 795-809.

Porter KG, Feig YS. (1980). The use of DAPI for identifying and counting aquatic microflora. Limnol Oceanogra 25: 943-948.

Smith JE, Shaw M, Edwards RA, Obura D, Pantos O, Sala E et al. (2006). Indirect effects of algae on coral: algae-mediated, microbe-induced coral mortality. Ecol Letters 9: 835-845.

Tanaka Y, Miyajima T, Watanabe A, Nadaoka K, Yamamoto T, Ogawa H. (2011). Distribution of dissolved organic carbon and nitrogen in a coral reef. Coral Reefs 30: 533-541.

Thurber RV, Willner-Hall D, Rodriguez-Mueller B, Desnues C, Edwards RA, Angly F et al. (2009). Metagenomic analysis of stressed coral holobionts. Environ Microbiol 11: 2148-2163.

Voss JD, Richardson LL. (2006). Nutrient enrichment enhances black band disease progression in corals. Coral Reefs 25: 569-576.

Supplementary Information accompanies the paper on The ISME Journal website (http://www.nature.com/ismej) 